\title{
Korelasi Tingkat Seismisitas dan Periode Ulang Gempa Bumi di Kepulauan Mentawai dengan Menggunakan Metode Guttenberg- Richter
}

\author{
Rahma Fidia $^{1 \text {,* }}$, Dwi Pujiastuti ${ }^{1}$, Andiyansyah Z.Sabarani ${ }^{2}$ \\ 'Laboratorium Fisika Bumi, Jurusan Fisika \\ Fakultas Matematika dan Ilmu Pengetahuan Alam Universitas Andalas \\ Kampus UNAND Limau Manis, Padang, 25163, Indonesia \\ ${ }^{2}$ Badan Meteorologi Klimatologi dan Geofisika, Padang Panjang, 27118 \\ *rahmafidia50@gmail.com
}

\begin{abstract}
ABSTRAK
Analisis tingkat seismisitas dan periode ulang gempa bumi berdasarkan magnitudo telah dilakukan pada daerah Kepulauan Mentawai dan sekitarnya. Data yang digunakan adalah gempa bumi dengan magnitudo sama atau besar dari 5 Skala Richter dan kedalaman 0-100 km untuk periode 1914-2015. Data ini bersumber dari katalog ISC (International Seismological Centre) dan BMKG Padang Panjang. Tingkat keaktifan gempa bumi dihitung dengan menggunakan metode Likelihood, sedangkan nilai periode ulang gempa dihitung dengan menggunakan metode Guttenberg-Richter. Berdasarkan hasil perhitungan, diperoleh nilai $b$ sebesar 0,8372 dan nilai $a$ sebesar 6,8094 serta nilai indeks seismisitas untuk magnitudo 5-8 berkisar antara 2,1580-0,0066. Hal ini menunjukkan bahwa daerah penelitian memiliki tingkat keaktifan kegempaan yang tinggi. Untuk magnitudo 5-8 diperoleh nilai periode ulang antara 0,4633150,5033 tahun. Secara umum dapat disimpulkan bahwa daerah Kepulauan Mentawai memiliki tingkat seismisitas tinggi dan rawan bencana gempa bumi. Hal ini dibuktikan dengan tingginya tingkat keaktifan gempa dan nilai periode ulang yang singkat.

Kata Kunci : Gempa, Metode Guttenberg-Richter, Indeks Seismisitas, Kepulauan Mentawai
\end{abstract}

\section{ABSTRACT}

An analysis of activity and periodicity prediction of earthquake based on magnitude in Mentawai island and surrounding had been done. The earthquake data that were analyzed are the ones which are equal and more than $5 \mathrm{SR}$, depth 0-100 km and happened in 1914-2015 (taken from ISC (International Seismological Center) catalog and BMKG Padang Panjang). The earthquake activeness rate was calculated using the Likelihood method, while the earthquake periodicity prediction was calculated using the Guttenberg-Richter method. It was found that $b$ and a values are 0,8372 and 6,8094, respectively with the seismicity index value for the magnitude of 5-8 varying from 2,1580 to 0,0066. This value indicates that the study areas have a high seismic activity level. The periodicity prediction of earthquake for magnitude of 5-8 varies from 0,4633 to 150,5033 years. Generally, it can be concluded that the region of Mentawai Islands has a high seismicity and earthquake prone. This is evidenced by the high level of liveliness of the earthquake and the short periodicity prediction.

Keywords: Earthquake, Guttenberg-Richter Method, Seismicity Index, Mentawai Islands.

\section{PENDAHULUAN}

Indonesia terletak pada batas pertemuan empat lempeng tektonik besar dunia yang sangat aktif, yaitu lempeng Eurasia, lempeng Pasifik, dan lempeng Indo-Australia serta satu lempeng mikro yaitu lempeng mikro Philipina. Pertemuan antar lempeng ini merupakan daerah sumber gempa bumi. Dampak kondisi tektonik yang sedemikian inilah yang menjadikan Indonesia sangat rawan terhadap bencana gempa bumi, karena itulah dengan sendirinya Kepulauan Indonesia juga rawan bencana tsunami (Bock, dkk., 2003).

Kepulauan Indonesia yang memiliki tingkat aktivitas gempa yang tinggi yaitu Sumatera. Di sepanjang pesisir barat pulau Sumatra, khususnya Kepulauan Mentawai, merupakan daerah yang sering mangalami gempa bumi dengan kedalaman dangkal. Hal ini akibat dari keadaan wilayah tersebut terletak pada salah satu kawasan pinggiran lempeng aktif yang terdapat interaksi antara lempeng Eurasian dan lempeng Indo-Australia. Interaksi tersebut menghasilkan pola penunjaman atau subduksi dan zona sesar mentawai.

Wilayah mentawai merupakan daerah yang patut diwaspadai karena terdapat energi yang tersimpan (energi ekspetasi) yang sewaktu waktu dapat dilepaskan dengan bentuk gempa bumi besar. Diawali dari hasil penelitian Geologi Institute Teknologi California, Kerry Sieh 
tahun 1994 dan geolog LIPI Danny Hilman Natawidjaja, segmen mentawai yang berlokasi di sisi barat sebelah luar pulau Siberut menyimpan potensi gempa 8,9 SR (Ardiyansyah, 2014). Pada tahun 2007, kembali terjadi gempa bumi berkekuatan 8.4 SR yang berpusat di perairan Sumatera Barat-Bengkulu (Natawidjaja, 2007). Pada tahun 2009, kawasan ini kembali terjadi gempa bumi berkekuatan 7,6 SR yang berpusat di lepas pantai Sumatera Barat (Sunarjo, dkk., 2010). Pada tahun 2010, juga kembali terjadi gempa bumi berkekuatan 7,2 SR yang berpusat di Pagai Selatan.

Untuk memperkecil dampak negatif dari gempa bumi seperti kerusakan bangunan, korban jiwa dan sebagainya, maka diperlukan upaya mitigasi salah satunya prediksi atau estimasi periode ulang gempa yang berpotensi menimbulkan kerusakan. Perkiraan gempa bumi mengindikasi bahwa gempa bumi dengan rentang magnitudo tertentu akan terjadi pada daerah tertentu pula. Hal ini hanya dapat digunakan untuk memprediksi kejadian gempa bumi sehingga dapat mencegah bahaya yang ditimbulkannya. Metode yang dapat digunakan untuk menghitung parameter keaktifan gempa bumi salah satunya adalah metode Guttenberg-Richter dapat diketahui secara kuantitatif tingkat keaktifan gempa bumi yang terdiri dari nilai $a$ (indeks seismisitas) dan nilai $b$ (tingkat resiko gempa) dan periode ulang untuk magnitudo tertentu di suatu daerah. Sedangkan pada metode Likelihood hanya menghitung secara statistik nilai parameter keaktifan gempa bumi, kelas interval magnitudo dapat diatur sedemikian rupa untuk menghindari kekosongan magnitudo pada kelas interval tertentu.

Chasanah, dkk, (2013) melakukan penelitian untuk menganalisis seismisitas dan periode ulang gempa bumi di Sumatera Barat pada periode 1961-2010. Metode yang digunakan dalam penelitiannya adalah metode Guttenberg-Richter. Dari hasil analisis didapatkan nilai $a$ sebesar 6,218 dan nilai $b$ sebesar 0,666, serta indeks seismisitas untuk magnitudo 5-9 SR yaitu antara 10,142-0,022. Periode ulang gempa bumi untuk rentang magnitudo 5-9 SR adalah berkisar antara 0,099-45,302 tahun atau setara dengan 36-16,535 hari. Budiman, dkk., (2011) melakukan penelitian tentang analisis periode ulang dan aktivitas kegempaan pada daerah Sumatera Barat dan sekitarnya dengan menggunakan metode Likelihood. Dari penelitian dihasilkan nilai $b$ antara $0,94-1,0$ dan nilai $a$ sekitar 6,7-7,13, sedangkan dari perhitungan periode ulang untuk magnitudo 5,0-6,5 SR memadai dijadikan acuan dalam memperkirakan perulangan gempa, tapi untuk magnitudo lebih besar dari 6,5 SR diperkirakan tidak akan terjadi.

Pada penelitian ini akan dilakukan analisis tingkat seismisitas dan periode ulang gempa bumi di Kepulauan Mentawai dengan menggunakan metode Guttenberg-Richter. Berdasarkan penelitian yang telah dilakukan, yang membedakan penelitian ini dengan penelitian sebelumnya yaitu terletak pada metode yang digunakan dan penempatan daerah penelitiannya.

\section{METODE}

Penelitian tentang analisis tingkat seismisitas dan periode ulang gempa bumi periode 1914-2015 di daerah Kepulauan Mentawai dikerjakan menggunakan metode GuttenbergRichter. Data yang digunakan dalam penelitian ini merupakan data sekunder, yaitu parameter gempa bumi, yang terdiri dari : kejadian gempa, letak episenter (latitude dan longitude), kedalaman, magnitudo gempa bumi. Data tersebut diperoleh melalui Badan Meteorologi Klimatologi dan Geofisika (BMKG) dan ISC(Internasioanal Seismological Center), periode tahun 1914-2015 dengan magnitudo yang digunakan $\geq 5$ SR dan kedalamaan $\geq 10 \mathrm{~km}$ sampai kedalamaan $\leq 100 \mathrm{~km}$. Dengan dearah penelitian berlokasi di $1.8^{\circ} \mathrm{LU}-3.5^{\circ} \mathrm{LS}$ dan $97.5^{\circ} \mathrm{BT}-$ $104^{\circ}$ BT. Dalam pengolahan data dilakukan beberapa langkah-langkah sistematis sebagai berikut :

5. Seluruh data gempa bumi diunduh dari tahun 1914 - 2015 di Wilayah Kepulauan Mentawai ISC yang berjumlah 2190 kejadian gempa dari berbagai wilayah yang ada di Sumatera.

6. Setelah data terkumpul, kemudian data disortir berdasarkan daerah penelitian didapatkan 466 kejadian gempa bumi yang ada di Kepulauan Mentawai.

7. Dari data 466 kejadian gempa yang telah ada, kemudian data kembali disortir berdasarkan magnitudo magnitudo $(\mathrm{M} \geq 5)$ dengan kedalaman $(10 \mathrm{~km} \leq \mathrm{h} \leq 100 \mathrm{~km})$ diperoleh 240 data. 
8. Frekuensi kejadian gempa dihitung berdasarkan magnitudonya dengan cara membuat kelas interval magnitudo, Frekuensi yang telah dihitung kemudian diplot grafiknya.

9. Selanjutnya nilai $b$ dan nilai a dihitung dengan menggunakan Persamaan 1 dan 2.

$$
b=\frac{\log e}{\bar{M}-M_{\min }}
$$

dan

$$
a=\log N\left(M \geq M_{0}\right)+\log (b \ln 10)+M_{0} * b
$$

dengan $M$ adalah magnitudo rata-rata, $M_{0}$ adalah magnitudo minimum dan $N$ adalah jumlah gempa dengan magnitudo lebih atau sama dengan $5 \mathrm{SR}(\mathrm{M} \geq 5 \mathrm{SR})$.

10. Selanjutnya Indeks seismisitas dihitung ke Persamaan 3 dan periode ulang gempa bumi dengan menggunakan Persamaan 4.

$$
N_{1}(M)=10^{a 1^{\prime}-M^{* b}}
$$

dengan $a=a-\log (b \ln 10)$. Selanjutnya periode ulang gempa bumi $(\theta)$ dalam satuan tahun dan ditentukan menggunakan Persamaan berikut.

$$
\vartheta=\frac{1}{N_{1}(M \geq 5)}
$$

11. Data gempa bumi diplot ke dalam peta daerah Kepulauan Mentawai dengan menggunakan program Generic Mapping Tools (GMT).

\section{HASIL DAN DISKUSI}

\subsection{Seismisitas Wilayah Kepulauan Mentawai}

Berdasarkan data gempa di Kepulauan Mentawai dari tahun 1914 - 2015 dapat diketahui peta seismisitas yang menggambarkan sebaran gempa di wilayah Kepulauan Mentawai. Pada Gambar 1 dapat dilihat bahwa sepanjang Pesisir Barat Pulau Sumatera, khususnya Kepulauan Mentawai merupakan daerah yang sering mengalami gempa bumi yang di dominasi oleh gempa kedalaman dangkal.

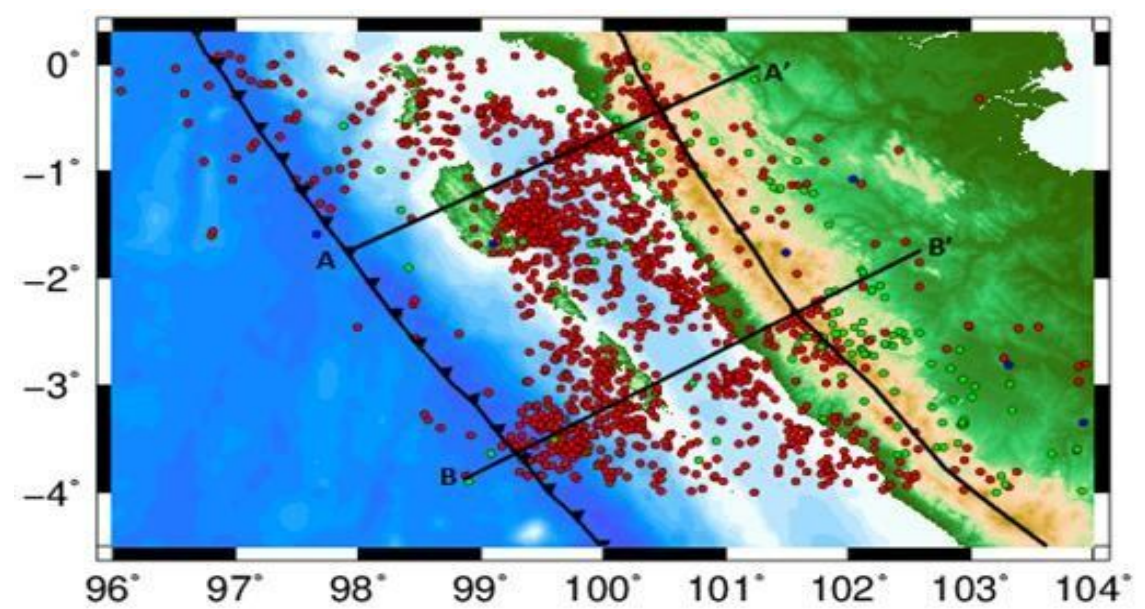

Gambar 1 Peta seismisitas daerah sekitar Kepulauan Mentawai (data periode 1914-2015)

Pada Gambar 1 terlihat penampang A-A' melintang melewati empat segmen sesar aktif Sumatera Barat yaitu segmen Sumpur $(0.1 \circ \mathrm{N} \sim 0.3 \circ \mathrm{N})$, segmen Sianok $(0.7 \circ \mathrm{S} \sim 0,1 \circ \mathrm{N})$, segmen Sumani $\left(1.0^{\circ} \mathrm{S} \sim 0.5 \circ \mathrm{S}\right)$, dan segmen Suliti $\left(1.75^{\circ} \mathrm{S} \sim 1.0 \circ \mathrm{S}\right)$, sedangkan penampang B-B' melitang melalui segmen sesar Mentawai. Pada Gambar 1 dapat dilihat bahwa sebaran gempa bumi yang terjadi di Kepulauan Mentawai bervariasi tergantung pada kedalaman serta magnitudo gempa. Berdasarkan Gambar 1 terlihat bahwa kepulauan Mentawai didominasi oleh gempa bumi dengan kedalam dangkal dengan magnitudo diatas 5 SR, yang ditunjukkan oleh simbol yang 
berwarna merah, sedangkan untuk lingkaran yang berwarna hijau merupakan gempa bumi dengan kedalaman menengah atau sedang. Gambar 1 menunjukkan bahwa gempa bumi yang paling sering terjadi adalah gempa bumi dangkal. Adapun gempa bumi dengan magnitudo dan kedalaman yang besar pernah terjadi, namun tidak sesering gempa bumi dangkal. Terlihat pada Gambar 1 dengan simbol berwarna biru merupakan gempa dengan magnitudo dan kedalaman yang besar terjadi hanya beberapa kali.

\subsection{Nilai $\boldsymbol{b}$ dan $\boldsymbol{a}$ dengan Menggunakan Metode Guttenberg-Richter}

Dari data yang telah disortir selanjutnya dihitung jumlah frekuensi gempa bumi berdasarkan interval magnitudonya kemudian disusun seperti pada Tabel 4.1, yang menunjukkan bahwa frekuensi terbesar terdapat pada magnitudo 5,0 - 5,4 yang berjumlah 161 kejadian gempa bumi, sedangkan frekuensi terkecil terdapat pada magnitudo 7,0 - 7,9 yaitu hanya terjadi 2 kali kejadian gempa bumi.

Tabel 1 Hasil Pengolahan Data Frekuensi Gempa Bumi Berdasarkan Magnitudo Dengan Metode Guttenberg-Richter

\begin{tabular}{cccc}
\hline $\begin{array}{c}\text { Interval } \\
\text { Magnitudo }\end{array}$ & $\begin{array}{c}\mathbf{N} \\
\text { (Frekuensi) }\end{array}$ & $\begin{array}{c}\mathbf{X} \\
\text { (Median) }\end{array}$ & $\mathbf{N} * \mathbf{X}$ \\
\hline $5,0-5,4$ & 161 & 5,2 & 837,2 \\
$5,5-5,9$ & 49 & 5,7 & 279,3 \\
$6,0-6,4$ & 16 & 6,2 & 99,2 \\
$6,5-6,9$ & 10 & 6,7 & 67 \\
$7,0-7,4$ & 2 & 7,2 & 14,4 \\
$7,5-7,9$ & 2 & 7,7 & 15,4 \\
Jumlah & 240 & 38,7 & 1312,5 \\
\hline
\end{tabular}

Dari perhitungan Tabel 1 didapatkan nilai $b$ (keadaan tektonik) sebesar 0,8372 dan nilai $a$ (keadaan seimisitas) sebesar 6,8094. Berdasarkan hasil yang didapat, terlihat bahwa wilayah Kepulauan Mentawai memiliki nilai $a$ yang relatif tinggi dan nilai $b$ yang relatif rendah. Tingginya parameter tektonik (nilai $a$ ) dan variasi spasial nilai $a$ pada wilayah Mentawai menunjukkan bahwa Mentawai memiliki aktivitas kegempaan yang relatif tinggi, sedangkan rendahnya parameter tektonik (nilai $b$ ) dan variasi nilai $b$ menunjukkan kondisi stress lokal yang tinggi dan berpotensi gempa bumi besar dan merusak. Berdasarkan nilai $b$ dan nilai $a$ dapat disimpulkan bahwa wilayah Kepulauan Mentawai memiliki tingkat stress yang tinggi menunjukkan bahwa Kepulauan Mentawai merupakan wilayah yang mempunyai peluang tinggi untuk terjadinya gempa besar di wilayah tersebut.

\subsection{Indeks Seismisitas}

Hasil indeks seismisitas untuk magnitudo 5-8 dapat dilihat pada Tabel 2 Hasil perhitungan lengkap dapat dilihat pada Lampiran 4. Berdasarkan Tabel 2 dapat diketahui nilai indeks seismisitas terbesar terdapat pada magnitudo 5 sebesar 2,1580, sedangkan untuk indeks seismisitas terkecil terdapat pada magnitudo 8 dengan nilai 0,0066 . Hasil tersebut menunjukkan bahwa tingkat kejadian gempa bumi pada daerah penelitian dengan magnitudo besar lebih sedikit dibandingkan degan tingkat kejadian gempa dengan magnitudo kecil. Semakin besar nilai indeks seismisitas maka semakin sering terjadi gempa bumi dan begitu juga sebaliknya. Hal ini akan mempengaruhi periode ulang gempa bumi berdasarkan magnitudo tertentu. 
Tabel 2 Hasil Perhitungan Indeks Seismisitas Gempa Bumi

\begin{tabular}{cc}
\hline Magnitudo & $\begin{array}{c}\mathbf{N 1}(\mathbf{M}) \\
\text { Indeks Seismisitas }\end{array}$ \\
\hline 5,0 & 2,158 \\
5,5 & 0,823 \\
6,0 & 0,313 \\
6,5 & 0,119 \\
7,0 & 0,045 \\
7,5 & 0,017 \\
8,0 & 0,006 \\
\hline
\end{tabular}

\subsection{Periode Ulang Gempa Bumi}

Pada Tabel 3 dapat diketahui bahwa gempa bumi dengan magnitudo 5 - 8 SR di wilayah Kepulauan Mentawai memiliki periode ulang yang berbeda-beda yaitu sekitar 0,4633 hingga 150,5033 tahun, yang kemudian dikonversi dalam hari yaitu antara rentang 169,1372 54933,7366 hari. Pada wilayah Kepulauan Mentawai, gempa dengan kekuatan 5,0 - 5,4 SR sering terjadi, hal ini dapat dilihat pada Tabel 3 bahwa gempa dengan magnitudo $\geq 5$ SR memiliki periode ulang yang relatif pendek. Sedangkan gempa bumi dengan magnitudo $\geq 8 \mathrm{SR}$ memiliki periode ulang yang cukup lama, sehingga gempa bumi dengan magnitudo $\geq 8$ jarang terjadi pada wilayah ini. Periode ulang gempa bumi selain dipengaruhi oleh magnitudo, indeks seismisitas serta nilai $b$ dan nilai $a$, juga dipengaruhi oleh hubungan antara frekuensi kejadian gempa bumi dengan magnitudonya.

Tabel 3 Hasil Perhitungan Periode Ulang Gempa Bumi

\begin{tabular}{cc}
\hline Magnitudo & Periode Ulang $(\boldsymbol{\theta})$ \\
\hline 5,0 & 0,463 \\
5,5 & 1,214 \\
6,0 & 3,185 \\
6,5 & 8,351 \\
7,0 & 21,895 \\
7,5 & 57,404 \\
8,0 & 150,503 \\
\hline
\end{tabular}

Berdasarkan Tabel 2 dan Tabel 3 dapat disimpulkan bahwa apabila nilai indeks seismisitas besar maka periode ulang singkat, sehingga nilai $b$ semakin besar dan nilai $a$ semakin kecil. Kondisi ini menunjukkan bahwa daerah tersebut memiliki aktivitas seismik yang tinggi sehingga rawan terjadinya gempa bumi dengan magnitudo $\geq 5$ dan sebaliknya. Apabila nilai indeks seismisitas kecil maka periode ulang akan semakin lama, sehingga nilai $b$ semakin kecil. Kondisi ini menggambarkan daerah penelitian memiliki energi besar yang tersimpan, dan diprediksi berpeluang terjadi gempa besar di daerah tersebut. Kondisi ini sesuai dengan sejarah kegempaan yang pernah terjadi di Wilayah Mentawai.

Untuk melihat lebih jelasnya lagi, dibuat grafik hubungan frekuensi gempa bumi dan magnitudo seperti Gambar 2. Pada Gambar 2 menunjukkan frekuensi gempa bumi terus mengalami kenaikan dari periode 1934 sampai 2015 untuk magnitudo 5,0 - 5,9. Hal ini dipicu oleh peningkatan aktivitas zona subduksi Lempeng Indo-Australia ke bawah Lempeng Eurasia di daerah Kepulauan Mentawai dan sekitarnya. Kejadian gempa bumi dengan skala besar lebih sedikit frekuensinya sehingga periode ulang akan semakin lama. Begitu sebaliknya, kejadian gempa bumi dalam skala kecil frekuensi kejadiannya lebih banyak sehingga periode ulang yang akan terjadi akan semakin pendek. Semakin besar magnitudo gempa bumi, maka periode ulang nya lebih lama, hal ini juga di dukung dalam teori elastisitas rebound yang menyatakan bahwa pergerakan lempeng yang mempunyai fase pengumpulan energi dalam jangka waktu lama kemudian masa pelepasan energi tersebut yaitu pada saat gempa bumi besar. Dengan kata lain semakin besar periode ulang suatu gempa bumi, semakin besar pula magnitudo gempa yang akan terjadi. 


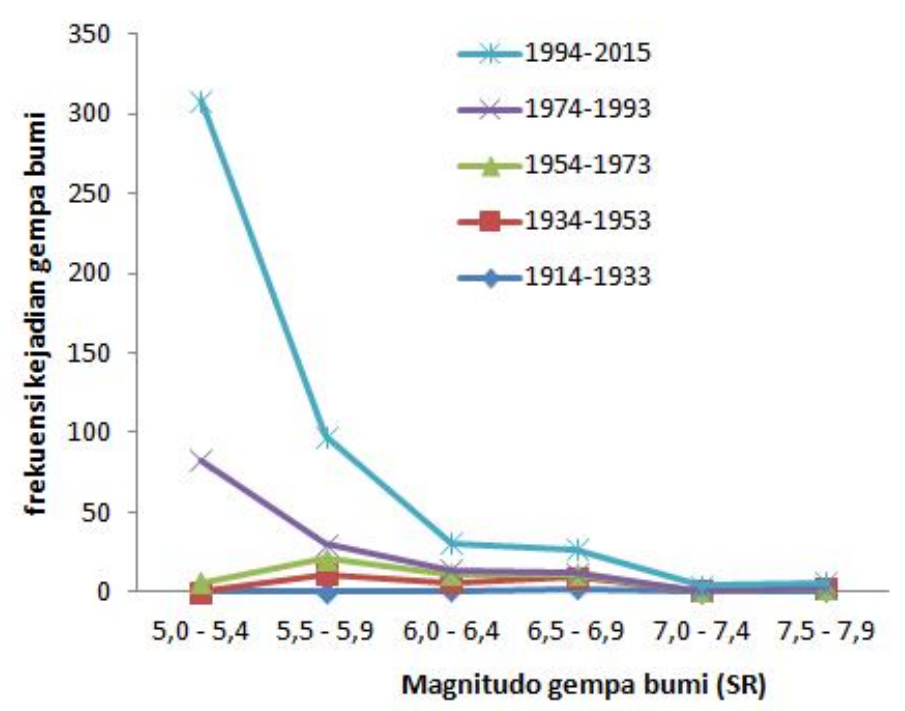

Gambar 2 Grafik Hubungan Frekuensi Gempa Bumi Terhadap Magnitudo

\section{KESIMPULAN}

Berdasarkan hasil analisis data gempa dari periode tahun 1914-2015 dengan menggunakan metode Guttenberg-Richter untuk daerah Kepulauan Mentawai dan sekitarnya dapat disimpulkan bahwa: Nilai parameter aktivitas gempa bumi untuk daerah penelitian diperoleh nilai $b$ sebesar 0,8372 dan nilai $a$ sebesar 6,8094 serta nilai indeks seismisitas untuk magnitudo 5 - 8 berkisar antara 2,1580 - 0,0066, Kondisi ini menunjukkan bahwa daerah Kepulauan Mentawai dan sekitarnya diprediksi memiliki tingkat keaktivan gempa yang tinggi dan memiliki energi besar yang masih tersimpan sehingga berpeluang terjadi gempa besar di wilayah tersebut. Hasil perhitungan periode ulang gempa bumi berbeda-beda untuk magnitudo 5-8 berkisar antara 0,4633 tahun - 150,5033 tahun.

\section{DAFTAR PUSTAKA}

Andiansyah, S., Jurnal Pusat Studi Jepang. 2, 1-8 (2014).

Budiman, A., Riva, N., dan Moh. Taufik, G., Jurnal Ilmu Fisika. 3, 55-61 (2011).

Bock, L. Y \& Prawirodirdjo, J. F, Journal of Geophysical Research. 5, 2367-2369 (2003)

Chasanah, U., Madlazim., Tjipto, p., Jurnal Ilmu Fisika.2, 1-6 (2013).

Natawidjaja, D.H., Gempa Bumi dan Tsunami Di Sumatera dan Upaya Untuk Membangkitkan Lingkungan Hidup yang Aman dari Bencana Alam, (LIPI, Jakarta, 2007), hal.20.

Sunarjo, Gunawan, M. T., Pribadi, S., Gempa Bumi edisi Populer, (BMKG, Jakarta, 2010), hal. 35. 